\section{United States Army Medical Library}

For all who must attempt to follow modern developments in human and veterinary medicine and in the branches of science associated with the study of disease, the Current List of Medical Literature (Washington 25, D.C. : U.S. Govt. Printing Office ; 9 dollars a year, 11.50 dollars a year foreign), now in its twentieth volume, continues to perform a valuable service. Issued monthly by the Army Medical Library, the purpose of this publication is to extend the services of the Army Medical Library to those who cannot use them in person. A recent issue of the Current List (20, No. 8; August 1951) contains a list, 150 pages long, of articles in a variety of journals printed in various languages, and also a subject and author index of them. The titles only of the articles are given. The list of journals dealt with by the Current List was published a year ago (19, No. 6 ; December 1950) and occupies ten pages of small type of that issue. The August 1951 issue prints a short additional list of journals. The Army Medical Library will lend without charge microfilm copies of original articles published in medical journals, and will sell microfilms and photoprints to those who wish to keep them. The Library will not reproduce books protected by copyright, nor complete issues of periodicals, unless the written permission of the copyright owner has been obtained; and it will not make more than one copy of any item. Requests must be made on the official order-form (supplied on application) and requests for loans must come through libraries or government or research institutions. The cost of microfilms is 50 cents for each fifty pages or fraction thereof from a single article. Photoprints cost 50 cents for each five pages or fraction thereof from a single article. All communications must be made to the Superintendent of Documents, U.S. Government Printing Office, Washington 25, D.C.

\section{Daily Food Intake of Rock Pipits}

AT a joint scientific meeting of the British Trust for Ornithology and the British Ornithologists' Union, held at the offices of the Zoological Society of London on January 22, Mr. John Gibb described the techniques by which he was able to measure the daily intake of food by an individual rock pipit Anthus spinoletta on a Cornish beach at Christmas-time. The food varied greatly from day to day according to what was available: certain foods, such as the winkle Littorina neritoides, were always present in great abundance, but were only taken when other and better foods, such as Idotea spp. and dipterous larvæ, were absent. The rate of defæcation by one rock pipit varied from about a fæces every $1 \frac{1}{2}$ minutes, when mostly Littorina were taken, to about once every 21 minutes, when mostly dipterous larvæ were taken. The opercula of the Littorina, and certain chitinous parts of the other foods, persisted in the fæces, and could be counted ; in this way, analysis of fæces confirmed the results obtained by direct observation. No stomach analyses were made. The dry weight of food eaten ranged from about $8 \mathrm{gm}$., when few Littorina were eaten, to about $25 \mathrm{gm}$., when many (about eleven thousand) Littorina were eaten, per day. Although Littorina neritoides were present at densities of up to about fifteen thousand per square metre, the rock pipits required to feed for more than 90 per cent of the day to obtain sufficient nutriment.

\section{Frank B. Jewett Fellowships: New Awards}

The American Telephone and Telegraph Co. has awarded Frank B. Jewett fellowships to the following: Dr. M. Gerstenhaber, a graduate of Yale University and the University of Chicago, for research in higher mathematics, particularly mapping problems in connexion with Riemannian manifolds, at the University of Chicago ; E. M. Henley, a graduate in electrical engineering of the College of the City of New York, for the study of new approaches to the meson theory of nuclear forces at the Institute for Advanced Study, Princeton; Dr. E. T. Onat, a graduate of the Technical University of Istanbul, for the continuation of research in the Graduate Division of Applied Mathematics of Brown University, on a second-order theory for the criterion of collapse in the plastic range; Dr. H. Helson, a graduate in mathematics of Harvard University, for work on the classification of the relations between the Wiener and Kolmogoroff prediction theory and certain questions in analytic function theory, to be undertaken at Yale University ; P. N. Schatz, a graduate in chemistry of the University of Pennsylvania, for research at the California Institute of Technology on the determination of the sign of the electric dipole moment of hydrogen chloride. These awards, which are made on the recommendation of a committee of seven from the Bell Telephone Laboratories, are designed to stimulate and assist research in the fundamental physical sciences by scientific workers who have recently received doctorates or are about to receive them. The fellowships carry a grant of 3,000 dollars to the recipient and 1,500 dollars to the institution at which the research is done.

\section{Standardization of Blood Transfusion Equipment}

AN international conference of medical and other authorities concerned with blood transfusion is meeting in London during March 3-5, with the object of seeking the international standardization of blood transfusion equipment. Hitherto most nations have tended to develop their own techniques, with the result that differences in the equipment used have prevented blood supplies from one country being quickly and easily used in another. The meeting is being arranged under the auspices of the International Organization for Standardization, and will be held at the British Standards Institution, Victoria Street, London, S.W.1. Twenty nations-principally European, together with the United States and several Empire countries-are sending delegates, while observers have been invited from the League of Red Cross Societies, the International Blood Transfusion Society, the Permanent International Commission for the Study of Medical Equipment and the World Health Organization. The chair will be taken by Sir Alan Drury, director of the Lister Institute.

\section{Physical Society's Annual Exhibition}

IN connexion with the Physical Society's forthcoming annual Exhibition of Instruments and Apparatus, to be held during April 3-8 (excluding Sunday) at the Imperial College of Science and Technology, South Kensington, London, S.W.7 (see Nature, January 19, p. 97), the following discourses will be delivered : April 4, at 6.45 p.m., "Engineering Supersonic Aerodynamics", by Mr. B. N. Wallis (Vickers-Armstrongs, Ltd.); April 7, at 6.45 p.m., "The Physical Basis of Colour Photography", by 